\title{
Thermal stress in the northern Carpathians and air circulation
}

\begin{abstract}
In mountain areas, air circulation plays a major role in the forming of the climate. This paper examines how it influences thermal stress in the northern Carpathians. The Niedźwiedż's classification of air circulation was applied. Thermal stress was assessed by Universal Thermal Climate Index (UTCl). Daily meteorological and circulation data for the period 1986-2015 were used for 20 stations in Poland, Slovakia and Ukraine. Air circulation was found to have a significant impact on thermal stress. The highest UTCI values are observed at $\mathrm{Ca}+\mathrm{Ka}$ (centre of the high and anticyclonic wedge or ridge of high pressure) and the lowest values at $\mathrm{N}+\mathrm{NE}$ and $\mathrm{W}+\mathrm{NW}$ circulation; at the Southward stations, UTCl is higher than in the Northward ones; thermoneutral days are more frequent on the southward than on the northward slopes; during N+NE, E+SE and W+NW circulation and for heat stress days, the greatest thermal privilege of the southward slopes is observed at E+SE, S+SW, $\mathrm{Ca}+\mathrm{Ka}$ and $\mathrm{Cc}+\mathrm{Bc}$ (centre of low and through of low pressure) types of circulation.

Keywords

Northern Carpathians $\bullet$ thermal stress $\cdot \mathrm{UTCl} \cdot$ air circulation
\end{abstract}

() University of Warsaw - Faculty of Geography and Regional Studies

\author{
Błażejczyk Krzysztof $\mathbb{C}^{1}$, Nejedlik Pavol $\mathbb{C}^{2}$, \\ Skrynyk Oleh $\mathbb{C}^{3}$, Halaś Agnieszka $\mathbb{C}^{3}$, \\ Skrynyk Olesya $\mathbb{C}^{4,5}$, Baranowski Jarosław ${ }^{1}$, \\ Mikulova Katarina $^{6}$ \\ 'Polish Academy of Sciences, Institute of Geography and \\ Spatial Organization, Climate Impacts Laboratory, Poland, \\ e-mail: k.blaz@twarda.pan.pl \\ e-mail: j.bar@twarda.pan.pl \\ ${ }^{2}$ Earth Science Institute of Slovak Academy of Science, Slovakia \\ e-mail: nejedlik@yahoo.com \\ ${ }^{3}$ Faculty of Geography and Regional Studies, University of Warsaw, \\ Poland \\ e-mail: o.skrynyk@uw.edu.pl \\ e-mail: aj.halas@student.uw.edu.pl \\ ${ }^{4}$ National University of Life and Environmental Sciences of \\ Ukraine, Ukraine \\ 5Ukrainian Hydrometeorological Institute, Ukraine \\ e-mail: skrynyk@nubip.edu.ua \\ ${ }^{6}$ Slovak Hydrometeorological Institute, Slovakia \\ e-mail: katarina.mikulova@shmu.sk \\ Received: 30 March 2020 \\ Accepted: 29 June 2020
}

Introduction

Thermal stress caused by meteorological conditions can influence different kinds of human activity, for example performance of work outdoors, sport, tourism, preventative healthcare, etc. Mountain regions are areas that are very sensitive to atmospheric factors and climate change (Migała 2005). The general features of the climate and its vertical zonation are very important due to their elevation above sea level (Błażejczyk et al.; 2013, Smith 2015; Rubel et al. 2017; Bokwa et al. 2019). Local weather is also influenced by exposure to predominant winds, depending on regional and local circulation patterns (Niedźwiedź 1983, 2012).

Within the large number of biometeorological indices that have been proposed for assessing bioclimatic conditions (Epstein \& Moran 2006; Błażejczyk et al. 2012; de Freitas \& Grigorieva 2017) the newly developed Universal Thermal Climate Index (UTCI), which defines thermal stress in humans, is more and more frequently applied in bioclimatic research (Morabito et al 2014; Urban \& Kysely 2014; Kolendowicz et al. 2018).

General climate and synoptic classifications are frequently used to explain how different air masses influence meteorological elements (temperature, wind, solar radiation, precipitation, etc.) (e.g. Lityński 1970; Kalkstein \& Nicholls 1996; Bissolli \& Dittmann 2001; Sheridan 2002; Niedźwiedź 2003; Bower et al. 2007; Huth et al. 2008; Vallorani et al 2017). Within COST Action 733, European researchers have conducted a review and harmonization of different synoptic classifications (e.g. Huth et al. 2008). There is some research dealing with the influence of air circulation on bioclimatic conditions. Ono and Kawamura (1991) assessed heat discomfort in southern Asia in relation to summer and winter monsoons. Kolendowicz et al. (2018) studied distribution of UTCl at southern Baltic and Nowosad et al. (2013) - in eastern Poland (Lublin) in relation to air circulation. The latest research conducted by Owczarek et al. (2019) describes the impacts of Grosswetterlagen weather types on UTCI distribution in northern Poland. Błażejczyk and Skrynyk (2019) applied the Niedźwiedź classification in Chornohora.

In mountain areas, climate features depend both on general regional factors and on vertical zonation of all meteorological variables: temperature, precipitation, cloudiness, insolation, etc. (Trepińska 2002; Migała 2005; Twardosz 1999, 2007; Baranowski 1999, 2003; Niedźwiedź 2003; Żmudzka 2009, 2011; Messeri et al. 2015; Sindosi et al. 2015; Łupikasza \& Niedźwiedź 2016; Błażejczyk 2019; Żmudzka \& Kulesza 2019). The important factors that have a major effect on the mountain climate are geographical position and orientation of the mountain ridges (Smith 2015). At elevated locations, lower air temperature and higher wind speeds cause that the human body is exposed to greater thermal stress. In addition, in the mountains, atmospheric conditions affecting humans can significantly differ over a relatively short horizontal distance (Błażejczyk et al. 2013; Bokwa et al. 2019). Until now there have not been many papers presenting the biometeorological specificity of mountain areas (Gaijć-Čapka \& Zaninović 1997; Mateeva \& Filipov 2003; Zaninović et al. 2006; 


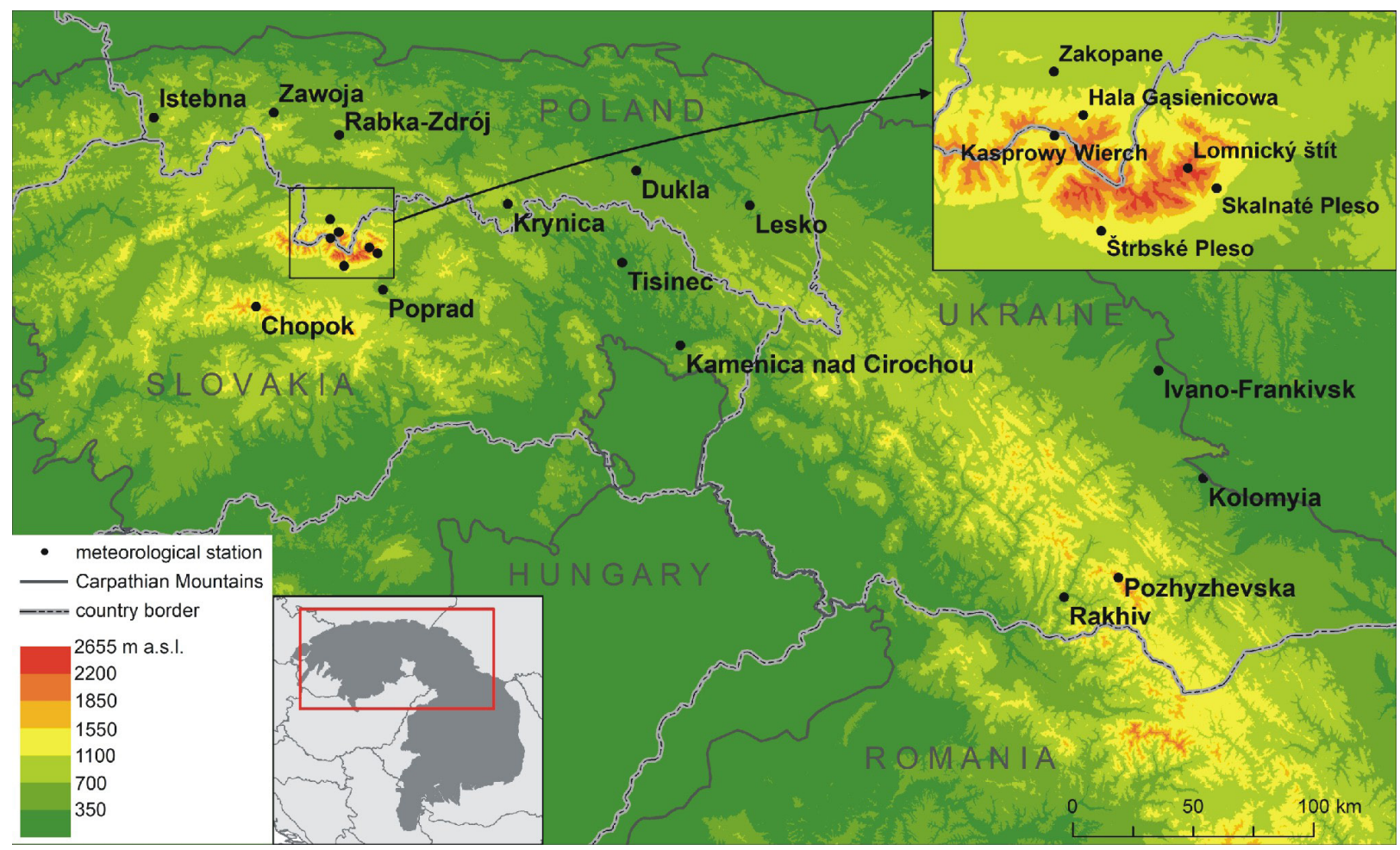

Figure 1. Northern Carpathians - location of meteorological stations used in research; the extent of the northern Carpathians is marked in the red rectangle. Source: produced by author

Miszuk 2008; Endler et al. 2010; Milewski 2013; Pecelj et al. 2017; Bokwa et al. 2019).

For the Carpathian region, there are also complex climatic characteristics (Konček 1974; Niedźwiedź 2012; Cheval et al. 2014; Spinoni et al. 2014; Dąbrowska \& Guzik eds. 2015). The general features of thermal stress conditions in the northern Carpathians were analysed by Błażejczyk et al. (2020), who concluded that 1) due to the higher altitude, UTCI values became lower, cold stress days are more frequent, and the number of heat stress days is reduced and at sites elevated $>1500 \mathrm{~m} \mathrm{ASL}$ is equal to 0,2 ) in eastern areas with sub-mountain, coline relief, cold stress is more evident and heat stress days are more frequent than in the western, montane landscape, 3) on the southward slopes of the Carpathian arc, heat stress is greater and more frequent then in north-facing areas.

This study is designed to examine how air circulation affects the spatial differentiation of thermal stress in the northern Carpathians. Attention is paid to exposure of meteorological stations to predominant flows of air.

\section{Materials and methods}

To analyse thermal stress in the Carpathians, we have used daily meteorological data from 20 stations of national weather networks of Poland, Ukraine and Slovakia for the period 1986-2015 (Fig. 1). For Poland, data are available at: Instytut Meteorologii i Gospodarki Wodnej Państwowy Instytut Badawczy 2020. Ukrainian and Slovak data were made available by archives of the Ukrainian Hydrometeorological Institute and Slovak Hydrometeorological Institute. In general, Polish stations represent the northward slopes of the Carpathian arc (opened to advections of air from N, NW and NE) and Slovak stations represent the southward slopes (influenced by air advection from $S$ and SE). Ukrainian stations are located both on the north- eastern (exposed to N, NE and E advections) and south-western slopes of the Carpathian arc (open to air flows from W, SW and S).

The Carpathians are a wide, crescent-shaped mountain ridge located in Central and Eastern Europe. They are the third longest mountain system in Europe (after the Urals and Scandinavian Mountains) extending for approximately 1300 $\mathrm{km}$ from the Danube gorge near Bratislava to the Iron Gate the Danube gorge near Orshova. The Carpathians consist of many geologically and orographically distinct mountain ridges (Raczkowska et al. 2012). The highest part of the mountains is the Tatra Massif (characterized by typical alpine relief), which consists of more than 50 peaks with an elevation above 2000 $\mathrm{m}$ (the culmination is Gerlachovský štít, $2655 \mathrm{~m} \mathrm{ASL}$ ). In the Eastern Carpathians, Chornohora is the highest ridge, with six peaks $>2000 \mathrm{~m}$ (Hoverla $2061 \mathrm{~m} \mathrm{ASL}$ ).

In the Carpathian Mountains, several vertical climate zones were distinguished by Hess (1965), namely: moderately warm (<700 m ASL), moderately cool (700-1100 m ASL), cool (1100$1550 \mathrm{~m} \mathrm{ASL})$, very cool (1550-1850 m ASL), moderately cold (1850-2200 m ASL), and cold (>2200 m ASL). For the Eastern Carpathians, Niedźwiedź (2012) has proposed modified borders of those zones, in respective order for those zones: 850, 850-1200, $1200-1550,1550-1850$ and $1850-2100 \mathrm{~m}$ ASL (there is no cold belt).

The Carpathian vertical climate zones correspond to zones observed in the European Alps. Rubel et al (2017) have applied the Koppen-Geiger climate classification to those zones, as follows: $<1050$ m ASL - Cfb climate (coline belt), 1050-1390 m ASL Cfc/Dfb climate (montane belt), 1390-1880 m ASL - Dfc climate (subalpine belt), 1880-3250 m ASL - ET climate (alpine belt).

Taking into account orographic, geological, and climatic facts discussed by Błażejczyk et al (2020) and the nomenclature proposed 
Table 1. Geographical information of studied meteorological stations

\begin{tabular}{|c|c|c|c|c|c|}
\hline $\begin{array}{l}\text { Name of station } \\
\text { (and abbreviation) }\end{array}$ & Latitude & Longitude & $\begin{array}{c}\text { Elevation above } \\
\text { sea level }(m)\end{array}$ & $\begin{array}{c}\text { Physiographical } \\
\text { type }\end{array}$ & Location \\
\hline \multicolumn{6}{|c|}{ Poland } \\
\hline Istebna-Kubalonka (IK) & $49^{\circ} 36^{\prime} \mathrm{N}$ & $18^{\circ} 54^{\prime} \mathrm{E}$ & 760 & Montane & Northward \\
\hline Zawoja (ZAW) & $49^{\circ} 37^{\prime} \mathrm{N}$ & $19^{\circ} 31^{\prime} \mathrm{E}$ & 720 & Montane & Northward \\
\hline Zakopane (ZAK) & $49^{\circ} 17^{\prime} \mathrm{N}$ & $19^{\circ} 57^{\prime} \mathrm{E}$ & 857 & Montane & Northward \\
\hline Hala Gąsienicowa (HG) & $49^{\circ} 14^{\prime} \mathrm{N}$ & $19^{\circ} 59^{\prime} \mathrm{E}$ & 1520 & Alpine & Northward \\
\hline Kasprowy Wierch (KW) & $49^{\circ} 13^{\prime} \mathrm{N}$ & $19^{\circ} 59^{\prime} \mathrm{E}$ & 1990 & Alpine & Peak \\
\hline Krynica (KRY) & $49^{\circ} 25^{\prime} \mathrm{N}$ & $20^{\circ} 58^{\prime} \mathrm{E}$ & 595 & Montane & Northward \\
\hline Rabka (RAB) & $49^{\circ} 37^{\prime} \mathrm{N}$ & $19^{\circ} 58^{\prime} \mathrm{E}$ & 510 & Montane & Northward \\
\hline Dukla (DUK) & $49^{\circ} 34^{\prime} \mathrm{N}$ & $21^{\circ} 41^{\prime} \mathrm{E}$ & 360 & Coline & Northward \\
\hline Lesko (LES) & $49^{\circ} 27^{\prime} \mathrm{N}$ & $22^{\circ} 20^{\prime} \mathrm{E}$ & 420 & Coline & Northward \\
\hline \multicolumn{6}{|c|}{ Ukraine } \\
\hline Ivano-Frankivsk (IF) & $48^{\circ} 53^{\prime} \mathrm{N}$ & $24^{\circ} 41^{\prime \prime} \mathrm{E}$ & 275 & Coline & Northward \\
\hline Kolomyia (KOL) & $48^{\circ} 32^{\prime \prime} \mathrm{N}$ & $25^{\circ} 03^{\prime \prime} \mathrm{E}$ & 298 & Coline & Northward \\
\hline Pozhyzhevska (POZ) & $48^{\circ} 09^{\prime \prime} \mathrm{N}$ & $24^{\circ} 32^{\prime \prime} \mathrm{E}$ & 1451 & Alpine & Northward \\
\hline Rakhiv (RAK) & $48^{\circ} 02^{\prime \prime N}$ & $24^{\circ} 11^{\prime \prime} \mathrm{E}$ & 431 & Coline & Southward \\
\hline \multicolumn{6}{|c|}{ Slovakia } \\
\hline Tisinec (TIS) & $49^{\circ} 13^{\prime} \mathrm{N}$ & $21^{\circ} 39^{\prime} \mathrm{E}$ & 216 & Coline & Southward \\
\hline Lomnicky Štít (LS) & $49^{\circ} 12^{\prime} \mathrm{N}$ & $20^{\circ} 13^{\prime} \mathrm{E}$ & 2635 & Alpine & Peak \\
\hline Skalnaté Pleso (SKP) & $49^{\circ} 11^{\prime} \mathrm{N}$ & $20^{\circ} 14^{\prime} \mathrm{E}$ & 1778 & Alpine & Southward \\
\hline Štrbské Pleso (STP) & $49^{\circ} 07^{\prime} \mathrm{N}$ & $20^{\circ} 04^{\prime} \mathrm{E}$ & 1322 & Montane & Southward \\
\hline Poprad (POP) & $49^{\circ} 04^{\prime} \mathrm{N}$ & $20^{\circ} 15^{\prime} \mathrm{E}$ & 694 & Montane & Southward \\
\hline Chopok $(\mathrm{CH})$ & $48^{\circ} 57^{\prime} \mathrm{N}$ & $19^{\circ} 36^{\prime} \mathrm{E}$ & 2005 & Alpine & Peak \\
\hline Kamenica nad Cirochou (KC) & $48^{\circ} 56^{\prime} \mathrm{N}$ & $22^{\circ} 00^{\prime} \mathrm{E}$ & 176 & Coline & Southward \\
\hline
\end{tabular}

Source: produced by author

by Rubel et al (2017), in this research meteorological stations were gathered in three groups: 1) Coline, with an elevation of $<500 \mathrm{~m}$ ASL, located mostly in the Eastern Carpathians, 2) Montane, with an elevation of 500-1400 m ASL, located mostly in the Western Carpathians, 3) Alpine, with an elevation of $>1400 \mathrm{~m} \mathrm{ASL}$, and alpine relief (Table 1).

For every station, daily data (for the period 1986-2015) on air temperature, relative humidity, total cloud cover, and wind speed at $10 \mathrm{~m}$ above ground for 12 UTC were used. The data for midday hours were applied due to their representativeness for any human activity (Jendritzky \& de Dear 2008). The Universal Thermal Climate Index (UTCl) was applied as a measure of thermal stress (Błażejczyk et al. 2012). The BioKlima@2.6 software package was used (Instytut Geografii i Przestrzennego Zagospodarowania PAN 2020) to calculate UTCI.

UTCI is defined as air temperature of reference condition causing the same model response (in sweat production, shivering, skin wettedness, skin blood flow, and in rectal, face and mean skin temperatures) as the actual conditions. The UTCI values are categorised according to 10 classes, from extreme cold stress to extreme heat stress (Bröde et al. 2012). In this research, three groups of UTCl categories are considered, namely: thermoneutral $\left(\mathrm{TN}, \mathrm{UTCl}=9.1-26.0^{\circ} \mathrm{C}\right)$, cold stress $(\mathrm{CS}$, $\mathrm{UTCl} \leq-13^{\circ} \mathrm{C}$ ) and heat stress ( $\left.\mathrm{HS}, \mathrm{UTCl}>32^{\circ} \mathrm{C}\right)$. The CS category combines UTCl classes of strong, very strong, and extreme cold stress, and the HS category the classes of strong, very strong and extreme heat stress.

To examine the effect of air circulation on thermal stress in the northern Carpathians, the authors used the Niedźwiedź calendar of circulation types (2019). This is a subjective classification based on the synoptic maps of Europe. The type of atmospheric circulation is determined by the direction of air mass advection and the kind of pressure pattern (a-anticyclonic, c - cyclonic). The area for which the calendar has been created extends from $49-51^{\circ} \mathrm{N}$ to $18-24^{\circ} \mathrm{E}$, covering southern Poland as well as part of the Czech Republic, Slovakia and Ukraine. In this paper, eleven circulation types were used, among which eight are advection types, two are non-advection types, and one is used in cases of unclassified situation or baric col (Table 2). The Niedźwiedź classification was applied to analyze the impact of air circulation on different atmospheric phenomenon occurrences, for example fog (Łupikasza \& Niedźwiedź 2016), precipitation (Twardosz 1999, 2007; Kholiavchuk \& Cebulska 2019) and secular changes in bioclimatic conditions (Błażejczyk et al. 2003).

The STATGRAPHICS Centurion XVI software package was used for statistical analysis. A 95\% confidence level was applied for verifying statistical significance of the studied relations. 
$\mathrm{UTCI}\left({ }^{\circ} \mathrm{C}\right)$

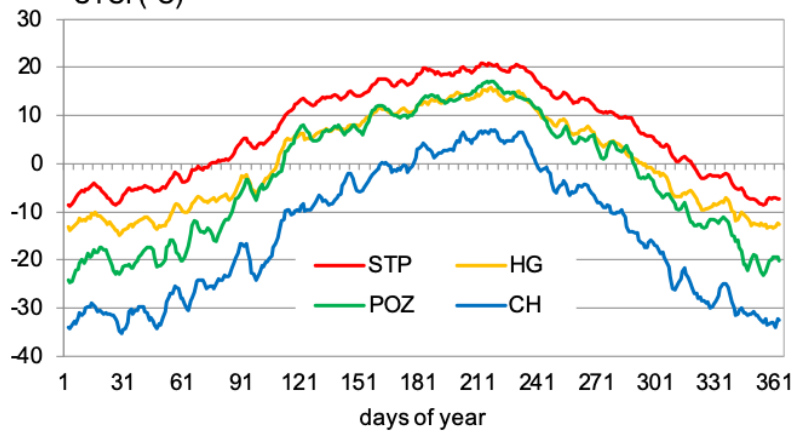

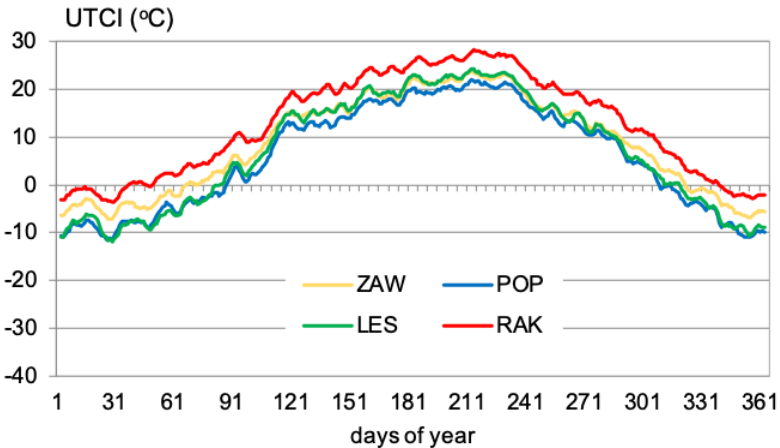

Figure 2. Average daily UTCI values in course of the year at selected meteorological stations, 1986-2015 Source: produced by author

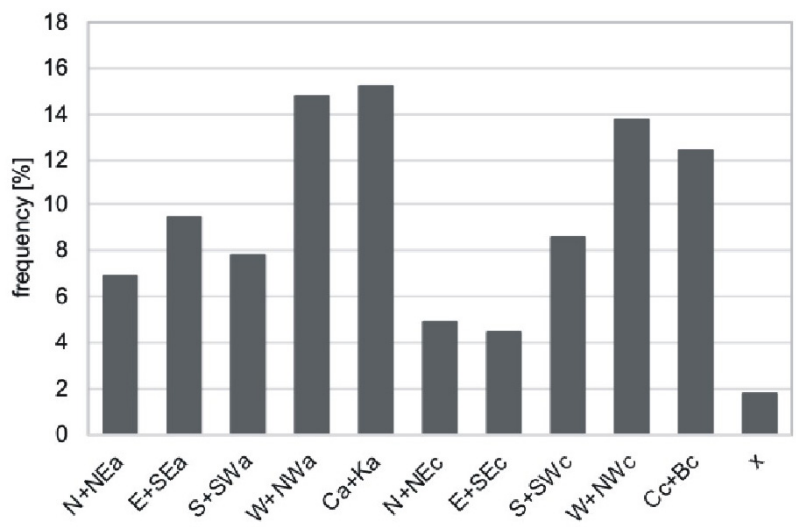

Figure 3. Annual frequency of circulation types during the period 1986-2015

Source: produced by author

Table 2. Air circulation types according to Niedźwiedź classification

\begin{tabular}{|c|c|}
\hline Anticyclonic situations: & Cyclonic situations: \\
\hline $\mathrm{N}+\mathrm{NEa}$ & $\mathrm{N}+\mathrm{NEc}$ \\
\hline $\mathrm{E}+\mathrm{SEa}$ & $\mathrm{E}+\mathrm{SEc}$ \\
\hline $\mathrm{S}+\mathrm{SWa}$ & $\mathrm{S}+\mathrm{SWc}$ \\
\hline $\mathrm{W}+\mathrm{NWa}$ & $\mathrm{W}+\mathrm{NWc}$ \\
\hline $\begin{array}{c}\mathrm{Ca}+\mathrm{Ka}-\text { centre of high and } \\
\text { anticyclonic wedge or ridge of } \\
\text { high pressure }\end{array}$ & $\begin{array}{c}\mathrm{C} \mathrm{c}+\mathrm{Bc}-\text { centre of low and } \\
\text { through of low pressure }\end{array}$ \\
\hline $\mathrm{x}-$ unclassified situation & \\
\hline
\end{tabular}

Source: adapted from Niedźwiedź (2019)

\section{Results}

\section{General characteristics of UTCI}

When analysing annual UTCI values, most intensive heat stress is found to occur in Rabka (Northward Montane station). There is noted highest mean yearly $\left(+13.5^{\circ} \mathrm{C}\right)$, UTCImax $>40^{\circ} \mathrm{C}$ and frequent occurrence of $\mathrm{HS}$ conditions $(4.6 \%$ of days yearly). High UTCl means (above $+10^{\circ} \mathrm{C}$ ) are also observed in Istebna and Krynica (Northward Montane stations) as well as in Kamenica and Rakhiv (Southward Coline stations). The absolute maximum $\mathrm{UTCl}>40^{\circ} \mathrm{C}$ was mostly registered at stations located in the eastern part of the area (TIS, KAM, IF, RAK, KOL). The lowest UTCI values, both mean $\left(<-11^{\circ} \mathrm{C}\right)$ and minimum $\left(<-60^{\circ} \mathrm{C}\right)$, are observed at most elevated Alpine stations in the Western Carpathians (KW, CH, LS) as well as at the POZ station in the Eastern Carpathians. At Alpine stations, cold stress days are noted frequently ( $>45 \%$ yearly). However, at stations located $>1400 \mathrm{~m} \mathrm{ASL}$ no days with heat stress are noted. On the contrary, HS days were recorded more frequently ( $>5 \%$ days per year) in stations situated on the southward slopes of the Eastern Carpathians (TIS, KAM, RAK) (Table 3).

Figure 2 presents average yearly UTCl course at selected stations. The first group (left panel) represents four high elevated (>1300 m ASL) locations in the Tatras (CH, HG and STP) and in Chornohora (POZ). The second group (right panel) illustrates Montane (ZAW, POP) and Coline (LES, RAK) stations situated in western and eastern parts of the studied area. In general, the yearly course of UTCl at all stations is the same. Visible UTCI decrease and increase phases occurred in approximately the same periods, and these were a warming phase in the third decade of January, and cooling periods in the first decade of April and between 5 and 13 May. On almost the same days, we also observe the annual maximum UTCI (30 July-3 August). These similarities over the course of a year demonstrate that the whole studied area is influenced by the same air circulation patterns

The lowest UTCl at stations of high elevation is highly evident, especially at Chopok. At stations of similar altitude, the Southward station STP is warmer than the Northward one (HG). At station of most eastern location (POZ), UTCI values in the cold season are significantly lower than in the Tatras. For the Montane and Coline stations, UTCI are similar over the course of the year, and average differences do not exceed $10^{\circ} \mathrm{C}$. The highest values are noted at the southernmost station (RAK) and the lowest ones at relatively elevated Poprad and at Northward Lesko located in the eastern part of the studied area.

\section{Atmospheric circulation}

During the period 1986-2015, anticyclonic circulation types were more frequent $(54.1 \%$ days) than cyclonic ones $(44.1 \%$ days). This period was characterized by the most frequent advections of air masses from the west and northwest, both anticyclonic $(14.7 \%)$ and cyclonic $(13.7 \%)$ as well as nonadvection types $\mathrm{Ca}+\mathrm{Ka}$ (15.2\%) and $\mathrm{Cc}+\mathrm{Bc}$ (12.4\%) (Fig. 3). Advection types are prevalent in the cold half-year, while nonadvection types are prevalent in the warm half-year. In summer (JJA), the frequency of circulation types is very similar to annual distribution, but with a higher occurrence of non-advection types: 
Table 3. Minimum (min), mean and maximum (max) annual UTCI values as well as yearly frequency of selected UTCI categories, 1986-2015

\begin{tabular}{|c|c|c|c|c|c|c|}
\hline \multirow{2}{*}{ Station } & \multicolumn{3}{|c|}{ UTCI values $\left({ }^{\circ} \mathrm{C}\right)$} & \multicolumn{3}{|c|}{ Frequency of UTCI categories (\%) } \\
\hline & $\min$ & mean & $\max$ & CS & TN & HS \\
\hline \multicolumn{7}{|c|}{ Northward } \\
\hline \multicolumn{7}{|c|}{ Coline } \\
\hline Dukla & -54.9 & 5.3 & 38.7 & 14.7 & 35.3 & 1.9 \\
\hline Lesko & -45.2 & 6.9 & 38.7 & 10.3 & 38.3 & 1.8 \\
\hline Ivano Frankivsk & -42.7 & 7.8 & 41.8 & 11.3 & 38.8 & 3.1 \\
\hline Kolomyia & -48.2 & 9.1 & 40.8 & 7.9 & 38.8 & 3.9 \\
\hline \multicolumn{7}{|c|}{ Montane } \\
\hline Istebna & -36.3 & 10.2 & 38.0 & 3.5 & 41.6 & 1.5 \\
\hline Zawoja & -35.3 & 8.5 & 40.1 & 6.6 & 42.1 & 1.5 \\
\hline Zakopane & -28.2 & 8.4 & 37.2 & 3.6 & 43.9 & 0.6 \\
\hline Krynica & -49.9 & 10.3 & 36.9 & 5.0 & 41.5 & 1.9 \\
\hline Rabka & -31.2 & 13.5 & 40.5 & 1.4 & 44.2 & 4.6 \\
\hline \multicolumn{7}{|c|}{ Alpine } \\
\hline $\begin{array}{c}\text { Hala } \\
\text { Gąsienicowa }\end{array}$ & -52.1 & 0.3 & 30.1 & 17.5 & 28.0 & . \\
\hline Pozhyzhevska & -66.0 & -2.7 & 33.7 & 24.1 & 31.8 & . \\
\hline \multicolumn{7}{|c|}{ Southward } \\
\hline \multicolumn{7}{|c|}{ Coline } \\
\hline Tisinec & -47.2 & 10.4 & 42.2 & 7.5 & 37.2 & 5.4 \\
\hline Kamenica & -47.4 & 11.3 & 41.3 & 5.0 & 39.5 & 5.1 \\
\hline Rakhiv & -36.4 & 12.5 & 41.6 & 2.2 & 43.6 & 5.6 \\
\hline \multicolumn{7}{|c|}{ Montane } \\
\hline Štrbské Pleso & -38.2 & 6.6 & 34.1 & 5.8 & 41.7 & 0.2 \\
\hline Poprad & -48.1 & 5.7 & 36.6 & 11.3 & 38.0 & 0.7 \\
\hline \multicolumn{7}{|c|}{ Alpine } \\
\hline Skalnaté Pleso & -60.3 & -1.3 & 28.2 & 20.7 & 23.6 & . \\
\hline \multicolumn{7}{|c|}{ Peaks (Alpine) } \\
\hline Chopok & -71.0 & -14.8 & 26.8 & 51.8 & 11.6 & . \\
\hline Lomnicky Štit & -73.5 & -15.7 & 24.2 & 52.2 & 6.4 & . \\
\hline Kasprowy Wierch & -60.8 & -12.1 & 26.8 & 45.7 & 11.4 &. \\
\hline
\end{tabular}

Source: produced by author

Ca+Ka (18.6\%) and Cc+Bc (16.7\%). In winter (DJF), circulation types with advection of air masses from the northwest sector W+NWa (21.2\%) and W+NWc (15.6\%) are dominant. In the transitional seasons, there is no single dominant type, and the frequency is quite even. In spring (MAM), days with non-advection types were more noticeable than other days (altogether 29.2\%). Spring is also the season with the highest frequency of circulation types with advection from the east (E+SEa, E+SEc, N+NEa, $\mathrm{N}+\mathrm{NEc}$ ) while in the autumn occurs the highest frequency of types with advection from southwest (S+SWa, S+SWc).

UTCI and air circulation

When looking for spatially averaged annual UTCI values for different types of circulation, the highest values are observed at $\mathrm{Ca}+\mathrm{Ka}$ (the average value for all considered stations is
$9.1 \pm 1.5^{\circ} \mathrm{C}$ ). A high UTCl is also noted at the $\mathrm{S}+\mathrm{SWa}$ and $\mathrm{Cc}+\mathrm{Bc}$ circulation types. However, the lowest values are related to the $\mathrm{N}+\mathrm{NEc}\left(-1.6 \pm 2.3^{\circ} \mathrm{C}\right)$ and $\mathrm{W}+\mathrm{NWc}\left(-0.8 \pm 2.4^{\circ} \mathrm{C}\right)$ circulation types. The highest mean annual UTCl is observed in Rabka $\left(17.8^{\circ} \mathrm{C}\right)$ during $\mathrm{S}+\mathrm{SWa}$ circulation. At this station, the highest annual $\mathrm{UTCl}$ values are also noted at almost all types of circulation. Only during $\mathrm{N}+\mathrm{NEc}$ and $\mathrm{Cc}+\mathrm{Bc}$ circulation types, the warmest is Rakhiv on the southward slopes of Chornohora and for E+SEc Kamenica on the southward slopes of Beskid Niski. The lowest annual UTCl is noted at Chopok Mt. $\left(-25.9^{\circ} \mathrm{C}\right)$ for the $\mathrm{N}+\mathrm{NEC}$ circulation type. For other circulation types, the lowest index values are recorded either at the summits of Chopok or Lomnicky Štit (Table 4).

At the Montane and Alpine stations located in the western part of the region, the highest mean annual UTCI values are 
MISCELLANEA GEOGRAPHICA - REGIONAL STUDIES ON DEVELOPMENT

Vol. $24 \cdot$ No. $3 \cdot 2020 \cdot$ pp. 147-160 •ISSN: 2084-6118 • DOI: 10.2478/mgrsd-2020-0022

Table 4. Mean annual UTCI values at different air circulation types, 1986-2015

\begin{tabular}{|c|c|c|c|c|c|c|c|c|c|c|c|}
\hline Measure & $\mathrm{N}+\mathrm{NEa}$ & E+SEa & $\mathrm{S}+\mathrm{SWa}$ & $\mathbf{W}+\mathbf{N W a}$ & $\mathrm{Ca}+\mathrm{Ka}$ & $\mathrm{N}+\mathrm{NEc}$ & E+SEc & $S+S W c$ & W+NWc & $\mathrm{Cc}+\mathrm{Bc}$ & $\mathbf{x}$ \\
\hline Average & $1.9 \pm 2.1$ & $4.9 \pm 1.6$ & $7.7 \pm 2.0$ & $1.1 \pm 2.1$ & $9.1 \pm 1.5$ & $-1.6 \pm 2.3$ & $5.0 \pm 1.9$ & $2.7 \pm 2.7$ & $-0.8 \pm 2.4$ & $7.2 \pm 2.1$ & $5.4 \pm 1.9$ \\
\hline $\begin{array}{l}\text { Highest } \\
\text { station }\end{array}$ & $\begin{array}{l}12.0 \\
\text { RAB }\end{array}$ & $\begin{array}{l}12.5 \\
R A B\end{array}$ & $\begin{array}{l}17.8 \\
\text { RAB }\end{array}$ & $\begin{array}{l}11.1 \\
\text { RAB }\end{array}$ & $\begin{array}{l}16.8 \\
\text { RAB }\end{array}$ & $\begin{array}{l}10.2 \\
\text { RAK }\end{array}$ & $\begin{array}{l}13.7 \\
\text { KAM }\end{array}$ & $\begin{array}{l}16.3 \\
R A B\end{array}$ & $\begin{array}{c}9.5 \\
\text { RAB }\end{array}$ & $\begin{array}{l}16.7 \\
\text { RAK }\end{array}$ & $\begin{array}{l}13.7 \\
\text { RAB }\end{array}$ \\
\hline $\begin{array}{l}\text { Lowest } \\
\text { station }\end{array}$ & $\begin{array}{c}-20.9 \\
\text { LS }\end{array}$ & $\begin{array}{c}-12.3 \\
\text { LS }\end{array}$ & $\begin{array}{c}-14.6 \\
\mathrm{CH}\end{array}$ & $\begin{array}{c}-21.1 \\
\text { LS }\end{array}$ & $\begin{array}{l}-8.5 \\
\text { LS }\end{array}$ & $\begin{array}{c}-25.9 \\
\mathrm{CH}\end{array}$ & $\begin{array}{c}-14.0 \\
\mathrm{CH}\end{array}$ & $\begin{array}{c}-25.3 \\
\mathrm{CH}\end{array}$ & $\begin{array}{c}-23.9 \\
\text { LS }\end{array}$ & $\begin{array}{c}-12.9 \\
\mathrm{CH}\end{array}$ & $\begin{array}{c}-12.6 \\
\text { LS }\end{array}$ \\
\hline
\end{tabular}

spatially averaged, the highest and the lowest values for all considered stations Source: produced by author
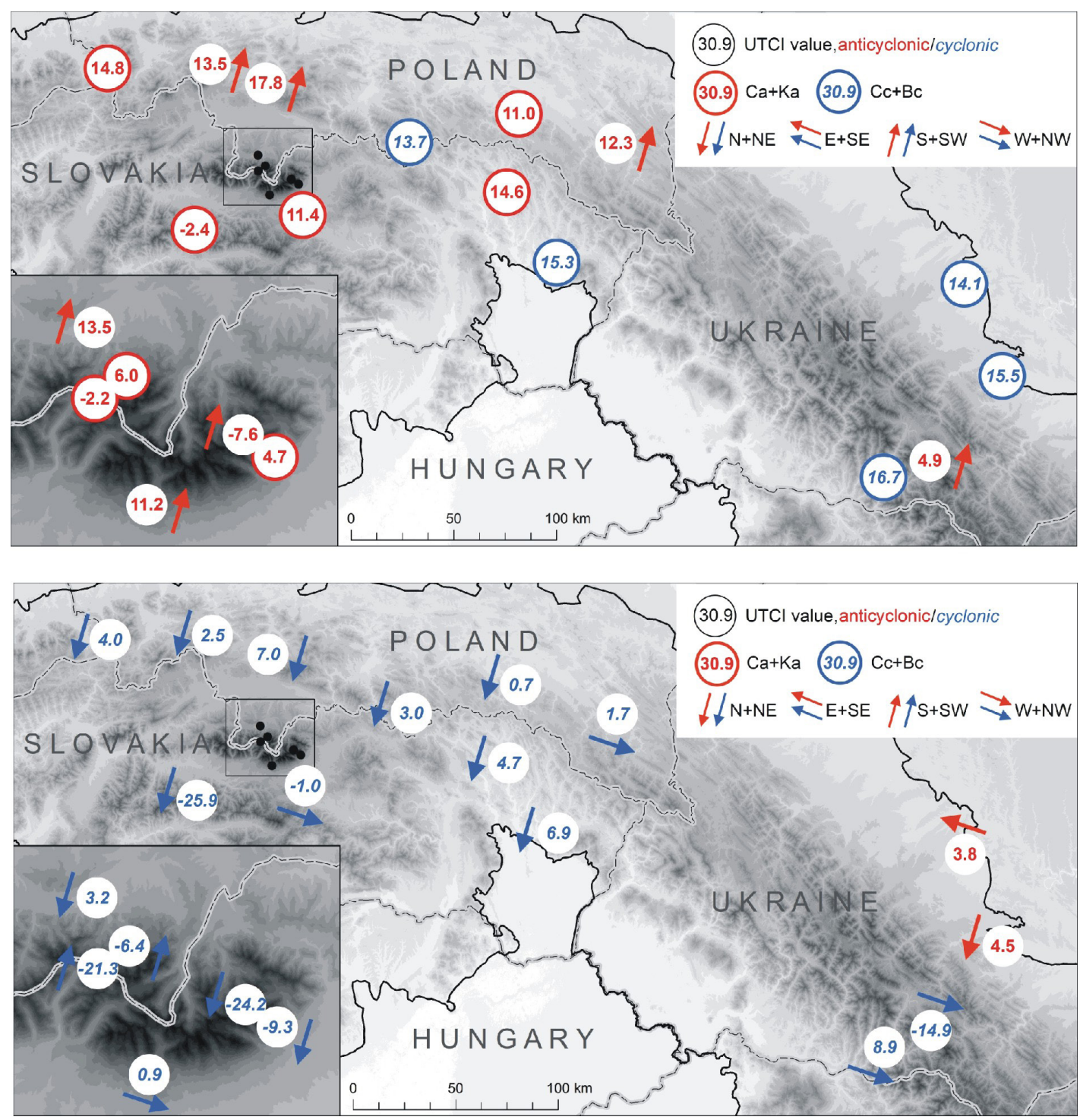

Figure 4. Highest (upper panel) and lowest (lower panel) mean annual UTCI $\left({ }^{\circ} \mathrm{C}\right)$ in relation to air circulation type Source: produced by author

mostly related to $\mathrm{S}+\mathrm{SWa}$ and $\mathrm{Ca}+\mathrm{Ka}$ air circulation types. However, at the Coline stations, situated mainly in the eastern part of the northern Carpathians, the analogical highest values of the thermal stress index are observed mostly during $\mathrm{Cc}+\mathrm{Bc}$ and S+SWa types of circulation (Fig. 4).
The lowest mean annual UTCI values are generally related to the N+NEc circulation type. At some stations (POP, STP, LES, RAK, POZ), the lowest means are observed for the W+NWc type. The situation at the $\mathrm{HG}$ and KW stations in the Polish Tatras was unusual, when the lowest annual UTCl is related to $\mathrm{S}+\mathrm{SWc}$ 


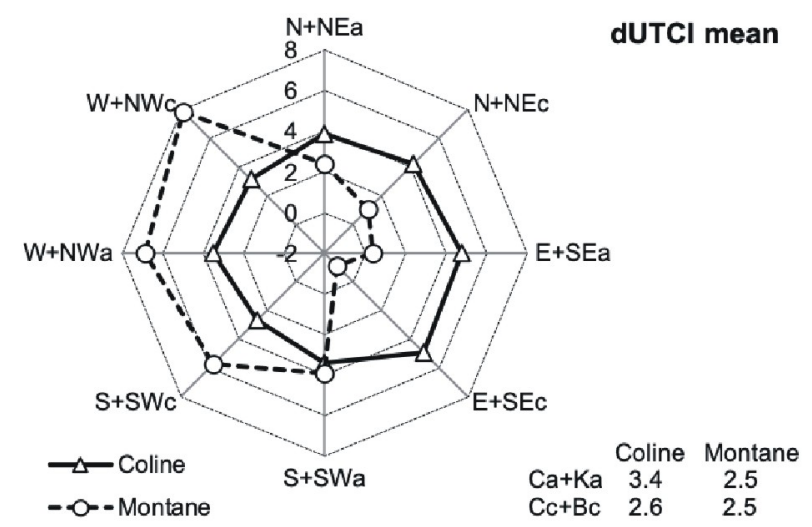

Figure 5. Differences in UTCI mean yearly values at Coline and Montane stations in relation to particular air circulation types Source: produced by author

circulation, and at the IF station (NE foot of the Carpathians), where the lowest annual values occur at the E+SEa circulation type. This needs more detailed research in the future.

As mentioned, the location of the station on the southward and northward slopes of the Northern Carpathian ridge affects both values and frequencies of particular UTCI categories. In our research, we considered differences in UTCl values and in the frequencies of UTCl categories between southward slopes and northward slopes stations located in the Coline and Montane physiographical types of area. In general, in the Southward Coline stations dUTCl, the means are $3.65^{\circ} \mathrm{C}$ higher than in Northward stations. In the Montane stations, such differences are slightly lower $\left(3.16^{\circ} \mathrm{C}\right)$. The dUTCI means vary significantly (with $p<0.05$ ) between particular circulation types. The greatest differences occur at advection from $\mathrm{W}+\mathrm{NWc}, \mathrm{W}+\mathrm{NWa}$ and $\mathrm{S}+\mathrm{SWc}\left(6-8^{\circ} \mathrm{C}\right.$ at the Montane stations) and $\mathrm{E}+\mathrm{SEc}, \mathrm{E}+\mathrm{SEa}$ and $\mathrm{N}+\mathrm{NEc}\left(4-6^{\circ} \mathrm{C}\right.$ at the Coline stations) (Fig. 5).

At the majority of stations, the highest UTCI maximum occurred during cyclonic air advection from $\mathrm{S}+\mathrm{SW}$ as well as for the $\mathrm{Cc}+\mathrm{Bc}$ circulation type. The SKP station is an exception, where the highest UTCImax was recorded at the $\mathrm{N}+\mathrm{NWa}$ advection. In general, in stations situated in the eastern part of the region, UTCI max are higher than in stations at the western edge of the Carpathians (Fig. 6).

The lowest UTCImin values occur mostly during N+NE and $\mathrm{E}+\mathrm{SE}$ advection. However, at some stations (IK, IF and KW), the lowest UTCImin was observed during S+SW (anticyclonic or cyclonic) circulation. There are also differences between western (warmer, with higher UTCImin) and eastern (cooler, lower UTCImin) parts of the studied region (Fig. 6).

In general, dUTCImin values are significantly higher than dUTCImax (respectively 4.95 vs. $2.36^{\circ} \mathrm{C}$ for the Coline stations and 8.31 vs $0.21^{\circ} \mathrm{C}$ for the Montane stations). The highest dUTCImax $\left(2-4^{\circ} \mathrm{C}\right)$ were found for $\mathrm{E}+\mathrm{SEc}, \mathrm{E}+\mathrm{SEa}, \mathrm{W}+\mathrm{NWa}$ and $\mathrm{W}+\mathrm{NWc}$ advections for the Coline stations as well as for $\mathrm{N}+\mathrm{NEa}$ and $\mathrm{W}+\mathrm{NWa}$ (Montane stations). In the case of dUTCImin, there are significant differences between particular circulation types (from approximately -1 to approximately $15^{\circ} \mathrm{C}$ ). The highest dUTCImin $\left(>7^{\circ} \mathrm{C}\right)$ were recorded during $\mathrm{S}+\mathrm{SWc}, \mathrm{S}+\mathrm{SWa}$, $\mathrm{N}+\mathrm{NWc}, \mathrm{E}+\mathrm{SEc}$ and $\mathrm{E}+\mathrm{SEa}$ (Montane stations) as well as $\mathrm{S}+\mathrm{SWa}$ and $\mathrm{W}+\mathrm{NWa}$ (Coline stations) air advection (Fig. 7).

Seasonal and regional variability in dUTCI values have been observed. On average, Coline Southward stations represent a higher mean, maximum and minimum UTCI. However, depending on the season, the warming potential of various advection types is different. In spring (MAM), the highest dUTCl is noted during air flow from N+NE, S+SE and W+NW. In summer (JJA), the northward slopes are mostly warmer at $E+S E$ and $\mathrm{Cc}+\mathrm{Bc}$ advections. During the autumn (SON) and winter (DJF) months, high dUTCImean and dUTCImax values occur mostly at N+NE and S+SE circulation. However, dUTCImin is elevated at S+SW and $\mathrm{W}+\mathrm{NW}$ advection. In general, in SON and DJF months, the dUTCImean is significantly higher $\left(3.9-4.2^{\circ} \mathrm{C}\right)$ than in spring and summer. The highest dUTCImax is noted in autumn and dUTCImin is the highest in winter (Table 5).

At the Montane stations, the highest warming potential of Southward locations is observed for dUTCImin (from $5.5^{\circ} \mathrm{C}$ in JJA to $10.6^{\circ} \mathrm{C}$ in MAM) and the highest values reach approximately $21^{\circ} \mathrm{C}$ (at $\mathrm{S}+\mathrm{SWc}$ and $\mathrm{Cc}+\mathrm{Bc}$ circulation). The lowest WP was found for maximum UTCI values. The average dUTCImax varies from $0.1^{\circ} \mathrm{C}$ in $\mathrm{JJA}$ to $1.1^{\circ} \mathrm{C}$ in MAM. It reached its highest values $\left(8^{\circ} \mathrm{C}\right)$ in winter, at $\mathrm{W}+\mathrm{NWc}$ advection. The average dUTCImean varies between $1.1^{\circ} \mathrm{C}$ in summer to $5.1^{\circ} \mathrm{C}$ in winter. In all seasons, mostly elevated dUTCImean are observed at the $\mathrm{W}+\mathrm{NWc}$ circulation type. During E+SEc advection, southward slopes are cooler than northward slopes when considering the differences in both UTCImean and UTCImax (Table 5).

Single extremely low or extremely high UTCl can be a result of different factors such as season, air circulation, ASL elevation and specific location of a station. Thus to find more general regularities of thermal stress conditions we have considered frequencies of particular UTCl categories. As seen in table 5 , annual frequency of cold stress days varied from $2.2 \%$ in RAK to $52.3 \%$ in LS. Figure 8 shows that on the Northward slope stations, the highest frequency of CS days occurs during $\mathrm{N}+\mathrm{NEa}$ circulation, and varies from $4.8 \%$ in $\mathrm{RAB}$ to $22.4 \%$ in DUK. At the Southward and Peak stations there are different advections of predominate CS frequency (S+SE, $\mathrm{S}+\mathrm{SW}, \mathrm{N}+\mathrm{NW}$ ) which varies from $5.9 \%$ in RAK to $72.5 \%$ in $\mathrm{CH}$. Heat stress was not observed at Alpine stations of high elevation, and their highest annual frequency reached $5.6 \%$ in RAK. When considering advection types it was found that at the Polish Northward stations the highest occurrence of HS days $(4.1-9.3 \%)$ was related to $S+S W a$. In the eastern part of the studied region, HS days are most frequent $(7.5-12.1 \%)$ during $\mathrm{Cc}+\mathrm{Bc}$ circulation.

The annual amount of TN days varied from $6.4 \%$ in LS to $44.2 \%$ in RAB (Table 5). TN days are most frequent during $\mathrm{C} c+\mathrm{Bc}$ or $\mathrm{Ca}+\mathrm{Ka}$ circulation types, except RAB, SKP, KAM, RAK and POZ stations. The number of days is between $14.5 \%$ in LS (at $\mathrm{Ca}+\mathrm{Ka}$ advection) and $50.5 \%$ in RAK (at S+SEc air inflow) (Fig. 9).

When analysing differences in annual frequency of cold stress days (dCS), they are found to be more frequent in the Northward than in the Southward stations. For Montane areas, this difference is on average $-7.5 \%$ and are highest at N+NE, $\mathrm{S}+\mathrm{SE}$ and $\mathrm{W}+\mathrm{NW}$ circulation types. For the Coline stations, the average dCS is $-4.9 \%$ and the highest values occur at $\mathrm{S}+\mathrm{SW}$ and $\mathrm{W}+\mathrm{NW}$ advections. Average dTN and dHS values show that thermoneutral and heat stress days are more frequent on the Southward slope in comparison to the Northward slope stations. For the Coline areas, the greatest dTN occurs at N+NE and $\mathrm{dHS}-$ at $\mathrm{E}+\mathrm{SE}$ and $\mathrm{Ca}+\mathrm{Ka} / \mathrm{Cc}+\mathrm{Bc}$ circulation. At the Montane stations, the greatest dTN is observed at $\mathrm{W}+\mathrm{NW}$ and $\mathrm{N}+\mathrm{NEa}$ circulation. At the Montane stations, HS days occur sporadically, and there are few dHS (Table 6).

At the Coline stations in the summer months (JJA), no cold stress days were recorded, and the greatest dCS is observed in DJF especially at $\mathrm{N}+\mathrm{NE}$ circulation. The highest $\mathrm{dHS}$ was found for the summer months, mainly during $S+S W$ advection. At the Montane stations, dCS is higher than in the Coline 

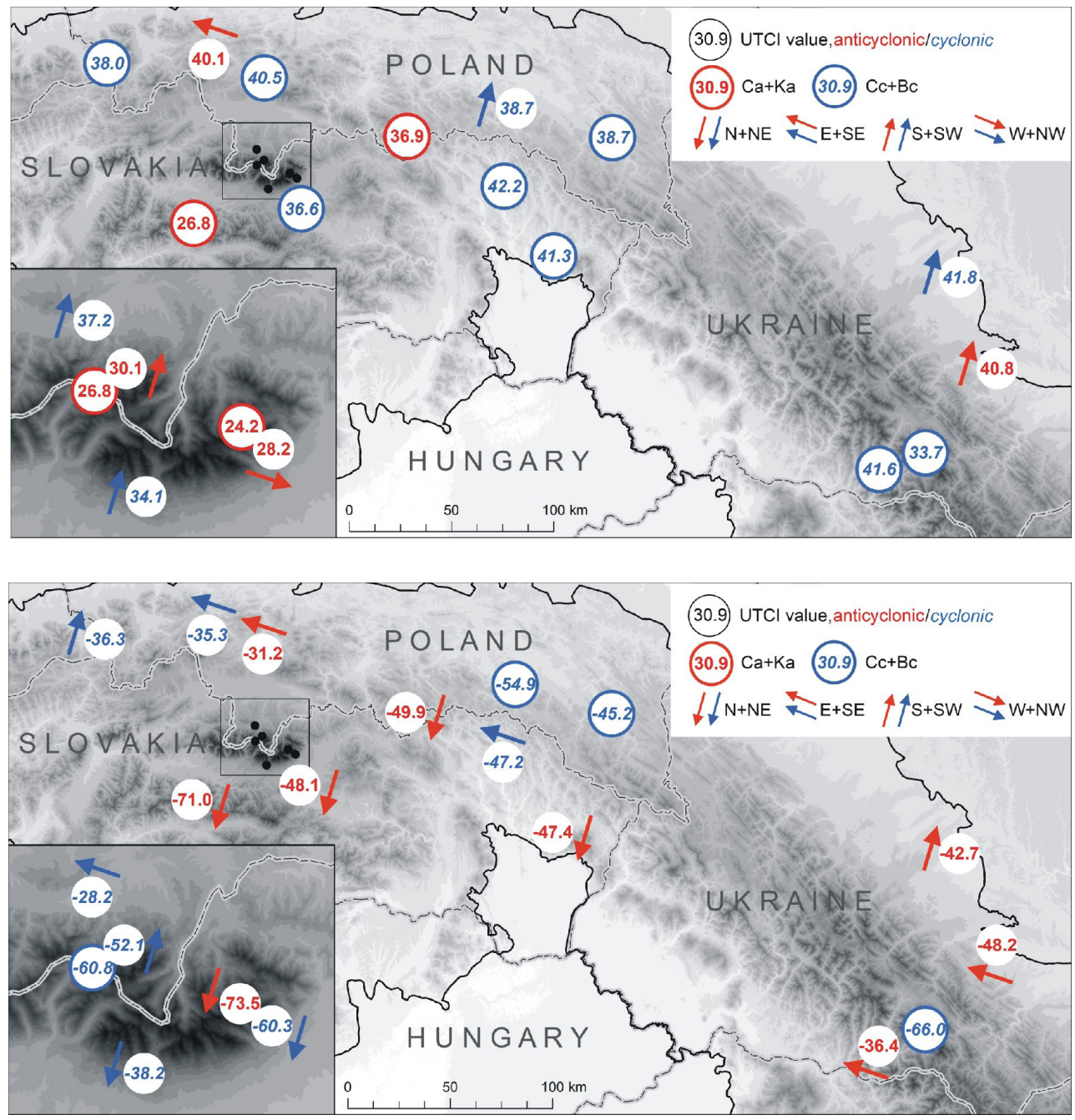

Figure 6. Maximum (upper panel) and minimum (lower panel) UTCI values registered at studied stations and air circulation type they have occurred. 1986-2015 Source: produced by author

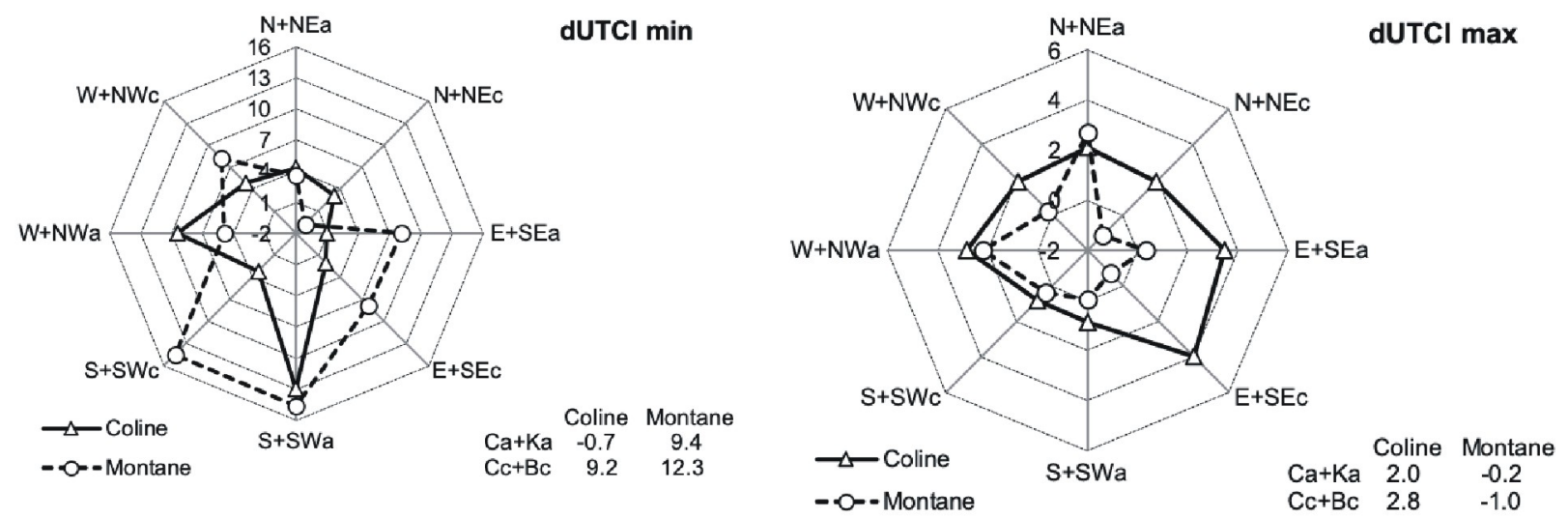

Figure 7. Differences in extreme yearly values of UTCImax (dUTCImax) and UTCImin (dUTCImin) at Coline and Montane stations in relation to particular air circulation types, 1986-2015

Source: produced by author 


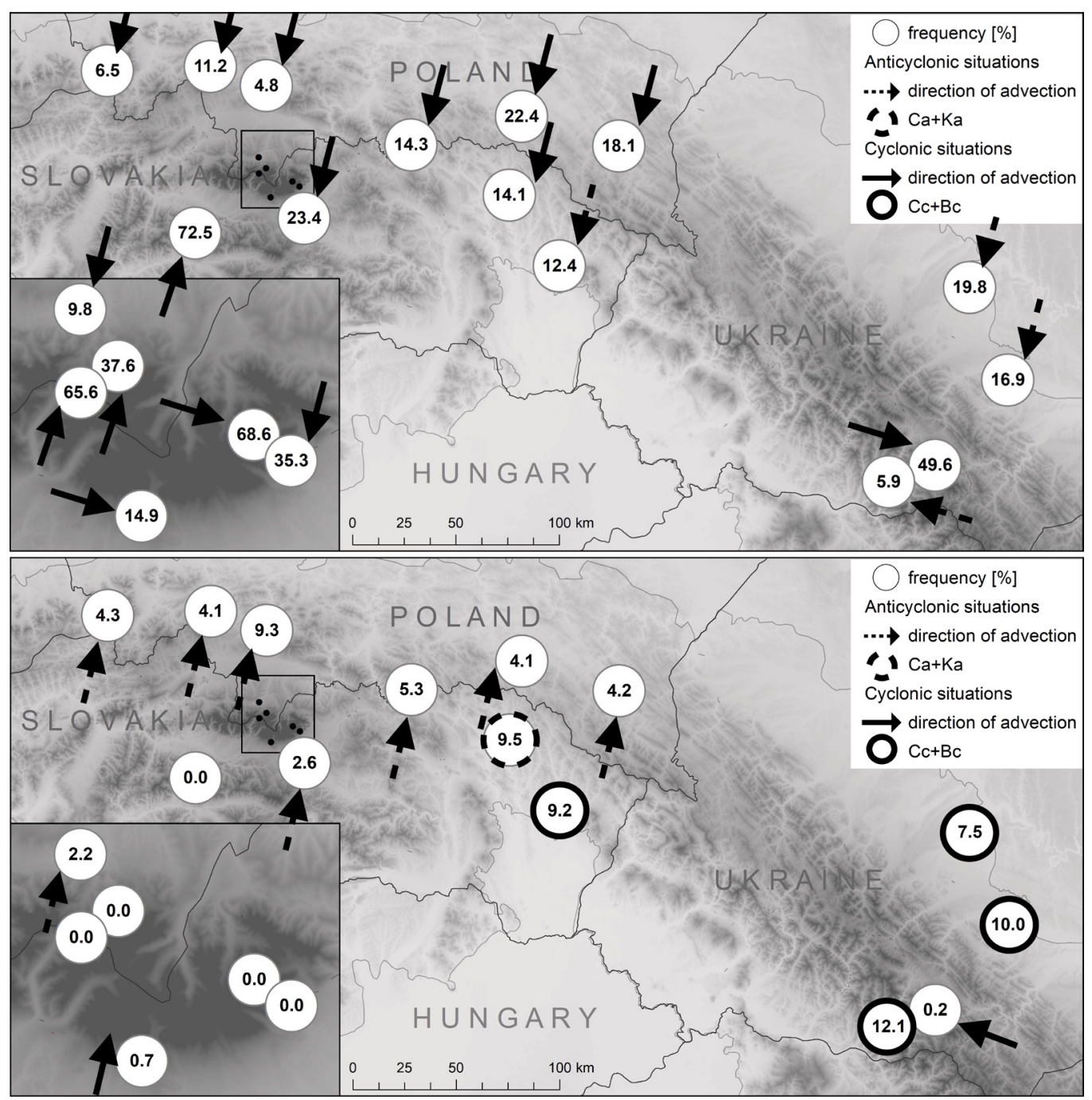

Figure 8. Highest frequency of cold stress days (upper panel) and hot stress days (lower panel) in relation to air circulation Source: produced by author

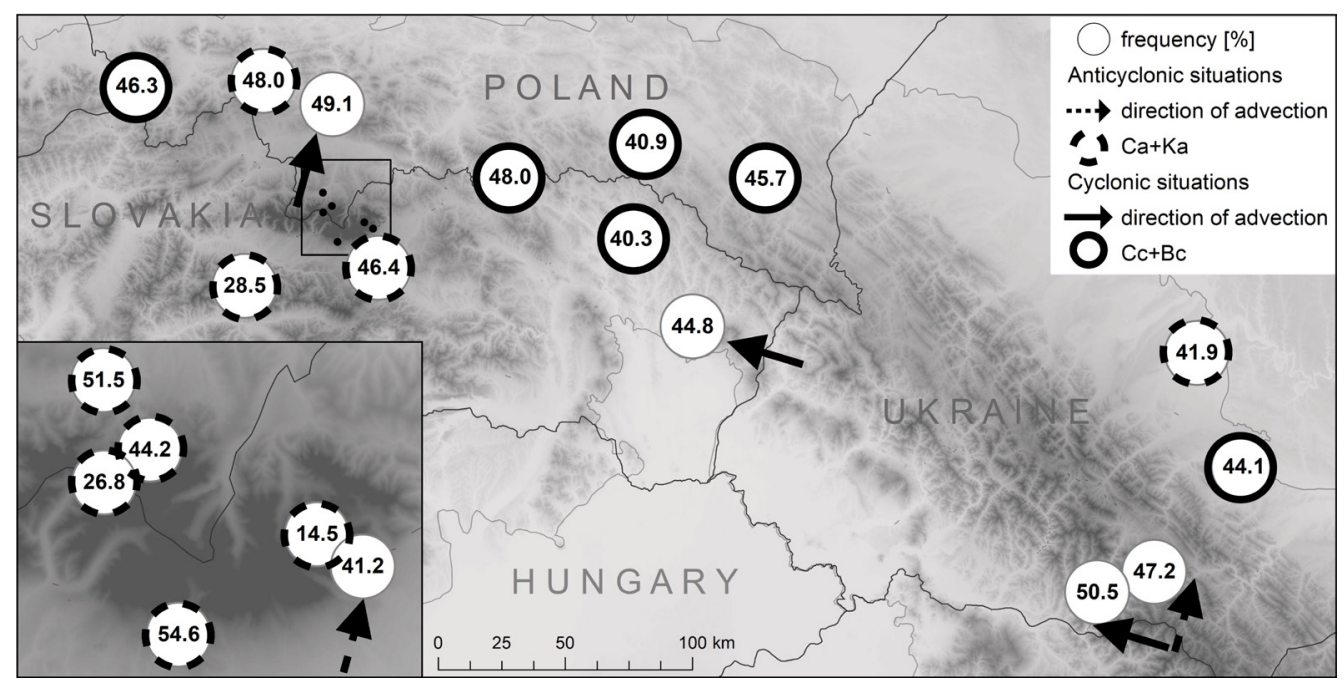

Figure 9. Highest frequency of thermoneutral days in relation to air circulation Source: produced by author 
MISCELLANEA GEOGRAPHICA - REGIONAL STUDIES ON DEVELOPMENT

Vol. $24 \cdot$ No. $3 \cdot 2020 \cdot$ pp. 147-160 •ISSN: 2084-6118 • DOI: 10.2478/mgrsd-2020-0022

Table 5. Differences in seasonal values of mean (dUTCImean). Maximum (dUTCImax) and minimum (dUTCImin) of the Universal Thermal Climate Index between Southward and Northward stations at particular air circulation types, 1986-2015

\begin{tabular}{|c|c|c|c|c|c|c|c|c|c|c|c|c|}
\hline \multirow{2}{*}{$\begin{array}{c}\text { Air } \\
\text { circulation } \\
\text { type }\end{array}$} & \multicolumn{4}{|c|}{ dUTCI mean } & \multicolumn{4}{|c|}{ dUTCI max } & \multicolumn{4}{|c|}{ dUTCI min } \\
\hline & MAM & JJA & SON & DJF & MAM & JJA & SON & DJF & MAM & JJA & SON & DJF \\
\hline \multicolumn{13}{|c|}{ Coline stations } \\
\hline $\mathrm{N}+\mathrm{NEa}$ & 3.6 & 3.8 & 4.0 & 4.5 & 2.2 & 2.4 & 5.0 & 4.2 & 1.5 & 7.3 & 2.7 & 3.8 \\
\hline $\mathrm{N}+\mathrm{NEc}$ & 4.3 & 2.8 & 5.0 & 6.0 & 2.5 & 1.9 & 0.4 & 4.3 & 7.0 & 0.5 & 5.1 & 1.9 \\
\hline $\mathrm{E}+\mathrm{Sea}$ & 4.3 & 3.4 & 5.2 & 5.9 & 0.8 & 3.5 & 2.3 & 3.0 & 0.2 & 2.6 & 4.8 & 1.0 \\
\hline $\mathrm{E}+\mathrm{Sec}$ & 4.6 & 3.5 & 5.1 & 6.2 & 4.0 & 4.0 & 4.7 & 2.3 & 5.3 & 6.0 & 2.6 & 2.5 \\
\hline S+Swa & 2.7 & 2.4 & 3.4 & 4.4 & 1.7 & 0.9 & 0.9 & 1.0 & 4.8 & 2.6 & 6.2 & 13.0 \\
\hline$S+S W c$ & 2.4 & 2.2 & 3.0 & 3.1 & 2.5 & 0.9 & 4.6 & 0.6 & 5.9 & 6.6 & 3.2 & 5.3 \\
\hline $\mathrm{W}+\mathrm{NWa}$ & 4.0 & 3.8 & 3.4 & 3.0 & 3.1 & 2.8 & 1.4 & 1.9 & 6.7 & 5.9 & 4.1 & 10.9 \\
\hline$W+N W c$ & 3.6 & 3.5 & 2.6 & 3.0 & 1.6 & 1.9 & 3.4 & -1.5 & 1.7 & 4.0 & 8.2 & 4.5 \\
\hline $\mathrm{Ca}+\mathrm{Ka}$ & 3.3 & 3.0 & 3.9 & 3.6 & 2.0 & 2.0 & 4.5 & 4.7 & 2.9 & 4.0 & 0.6 & -0.7 \\
\hline $\mathrm{Cc}+\mathrm{Bc}$ & 2.6 & 2.3 & 2.5 & 3.4 & 1.9 & 2.8 & 1.1 & 1.5 & 2.2 & 1.2 & -2.0 & 9.2 \\
\hline$x$ & 3.5 & 3.8 & 4.4 & 2.8 & 1.9 & 3.1 & 3.1 & 2.8 & 5.7 & 0.8 & 9.6 & 2.1 \\
\hline Average & 3.5 & 3.1 & 3.9 & 4.2 & 2.2 & 2.4 & 2.9 & 2.2 & 4.0 & 3.8 & 4.1 & 4.9 \\
\hline \multicolumn{13}{|c|}{ Montane stations } \\
\hline $\mathrm{N}+\mathrm{NEa}$ & 2.9 & 1.6 & 3.1 & 2.4 & 2.1 & 1.9 & 3.7 & 1.7 & 4.7 & 1.4 & 4.3 & 3.6 \\
\hline $\mathrm{N}+\mathrm{NEc}$ & 1.5 & 0.1 & 2.8 & -0.1 & 4.0 & -1.1 & 2.0 & 1.3 & 1.6 & -7.6 & 0.7 & -0.7 \\
\hline $\mathrm{E}+$ Sea & 1.3 & 1.4 & 0.2 & -0.9 & 0.9 & 0.3 & -0.2 & 0.0 & 7.1 & -3.8 & -1.3 & 5.4 \\
\hline $\mathrm{E}+\mathrm{Sec}$ & -0.4 & -0.7 & -1.7 & -1.4 & -0.4 & -0.7 & -2.2 & -0.8 & 2.2 & 4.8 & -1.5 & 7.9 \\
\hline S+Swa & 2.3 & 0.7 & 3.8 & 7.2 & -1.5 & 0.0 & -0.1 & 0.5 & 11.7 & 7.6 & 19.1 & 14.6 \\
\hline$S+S W c$ & 3.5 & 0.1 & 4.4 & 12.8 & 1.7 & 0.4 & 0.6 & 0.1 & 21.2 & 11.3 & 16.5 & 12.1 \\
\hline $\mathrm{W}+\mathrm{NWa}$ & 7.1 & 2.8 & 6.6 & 9.6 & 1.3 & 2.2 & 2.0 & 2.3 & 10.8 & 15.6 & 10.8 & 3.3 \\
\hline$W+N W c$ & 7.8 & 2.9 & 8.5 & 12.0 & 0.1 & 0.2 & 1.1 & 8.0 & 7.3 & 4.3 & 1.6 & 8.9 \\
\hline $\mathrm{Ca}+\mathrm{Ka}$ & 3.1 & 1.9 & 1.8 & 3.3 & 1.2 & -0.2 & -2.7 & 1.1 & 15.4 & 8.9 & 7.7 & 9.4 \\
\hline $\mathrm{Cc}+\mathrm{Bc}$ & 2.8 & 0.0 & 2.6 & 7.1 & 1.9 & -0.6 & 1.3 & -3.1 & 20.5 & 5.2 & 13.1 & 8.6 \\
\hline$x$ & 3.5 & 1.4 & 0.9 & 4.4 & 1.2 & -1.0 & 0.6 & -0.3 & 14.5 & 12.7 & 16.3 & 3.1 \\
\hline Average & 3.2 & 1.1 & 3.0 & 5.1 & 1.1 & 0.1 & 0.5 & 1.0 & 10.6 & 5.5 & 7.9 & 6.9 \\
\hline
\end{tabular}

Source: produced by author

stations in all seasons and they are greatest during S+SW and $\mathrm{W}+\mathrm{NW}$ circulation. In the case of thermoneutral days, there are significant seasonal differences. In the summer months, average dTN indicate that on the southward slopes there are less TN days than on the northward ones (of $-10.6 \%$ at the Coline and $-1.4 \%$ at the Montane stations). However, during the rest of the year there are more $\mathrm{TN}$ days on the southward than on the northward slopes, especially during N+NW (Montane stations) and E+SE/ $\mathrm{N}+\mathrm{NE}$ (Coline stations) circulation (Table 7).

\section{Discussion}

A mountain climate has several specific features. First of all, it is characterised by vertical zonations of essential meteorological elements as reported by Hess (1965) and Rubel et al. (2017). According to the increase of altitude, global solar radiation and insolation rise gradually (Baranowski 2003; Żmudzka \& Kulesza 2019). This is caused by two main factors: reduction of the optical mas of the atmoshere at elevated sites, and specific cloud conditions. Very often peaks of mountains are above the clouds covering valleys. 
Table 6. Differences in annual frequency of cold stress (dCS), thermoneutral (dTN) and heat stress days (dHS) between Southward and Northward stations

\begin{tabular}{|c|c|c|c|c|c|c|}
\hline \multirow{2}{*}{$\begin{array}{c}\text { Air circulation } \\
\text { type }\end{array}$} & \multicolumn{2}{|c|}{ dCS } & \multicolumn{2}{|c|}{ dTN } & \multicolumn{2}{|c|}{ dHS } \\
\hline & Coline & Montane & Coline & Montane & Coline & Montane \\
\hline $\mathrm{N}+\mathrm{NEa}$ & -5.9 & -3.7 & 2.6 & 7.1 & 1.4 & . \\
\hline $\mathrm{N}+\mathrm{NEc}$ & -7.9 & -2.5 & 7.3 & 2.7 & 0.2 & . \\
\hline $\mathrm{E}+\mathrm{SEa}$ & -6.0 & 1.3 & 0.8 & 0.9 & 3.6 & 0.0 \\
\hline $\mathrm{E}+\mathrm{SEc}$ & -5.4 & 1.6 & 5.6 & -2.1 & 4.7 & -0.1 \\
\hline $\mathrm{S}+\mathrm{SWa}$ & -4.5 & -10.0 & 0.9 & 1.0 & 4.1 & 0.3 \\
\hline$S+S W c$ & -4.6 & -18.1 & 1.2 & 1.8 & 2.7 & 0.4 \\
\hline $\mathrm{W}+\mathrm{NWa}$ & -7.1 & -15.0 & 1.5 & 9.1 & 0.9 & 0.0 \\
\hline W+NWc & -5.4 & -18.7 & 1.7 & 6.5 & 0.9 & 0.0 \\
\hline $\mathrm{Ca}+\mathrm{Ka}$ & -3.2 & -3.8 & -3.0 & 3.7 & 4.7 & 0.0 \\
\hline $\mathrm{Cc}+\mathrm{Bc}$ & -1.7 & -6.9 & -0.9 & 0.5 & 4.4 & 0.0 \\
\hline$x$ & -2.4 & -7.4 & -0.1 & -0.6 & 3.2 & . \\
\hline average & -4.9 & -7.5 & 1.6 & 2.8 & 2.8 & 0.1 \\
\hline
\end{tabular}

Source: Produced by author

The second feature of a mountain climate is decreasing air temperature due to increase in elevation (Trepińska 2002; Migała 2005; Smith 2015; Błażejczyk 2019), and this has a strong impact on sensible climate conditions. Many authors report a gradual orographical decrease in values of thermal sensation indices and other bioclimatic indicators in different mountain regions around Europe (Zaninović et al 2006; Endler et al. 2010; Bokwa et al. 2019).

The sensible climate is formed by several meteorological factors such as solar radiation, air temperature, air humidity and wind (Jendritzky \& de Dear 2008). In mountain areas, a significant increase in wind speed has been observed in comparison to submountain valleys (Baranowski 1999; Osadchyi et al. 2015; Błażejczyk 2019). Increased frequency of cold stress observed on mountain ridges (Błażejczyk et al. 2020) is caused by both low air temperature and high wind speed as reported for the Tatras by Błażejczyk et al. (2013) and for Chornohora by Błażejczyk \& Skrynyk (2019).

Air circulation plays an important role in creation of climatic and bioclimatic conditions. The Carpathians are a barrier for air masses. This significantly modifies the air temperature. In the northern Carpathians, the southward slopes are warmer than the northward ones (Hess 1965). In the Eastern and Southern Carpathians, there are thermal differences, which change according to season between the westward and eastward slopes (Cheval et al. 2014; Spinoni et al. 2014). Bioclimatic differences between the northward and southward slopes were reported by Błażejczyk et al. (2020).

In this research air circulation was found to have a significant impact on thermal stress in the northern Carpathians. Research of this kind has not been conducted frequently. However, in research conducted by Nowosad et al. (2013) and Owczarek et al. (2019) significant differences were reported in bioclimatic indices in particular air circulation types.

\section{Conclusions}

1) In general, the highest UTCI values $\left(9.1^{\circ} \mathrm{C}\right)$ are observed at $\mathrm{Ca}+\mathrm{Ka}$ circulation types. A slightly lower UTCI $\left(>7^{\circ} \mathrm{C}\right)$ is also noted at $\mathrm{S}+\mathrm{SWa}$ and $\mathrm{Cc}+\mathrm{Bc}$ types. However, the lowest values are related to $\mathrm{N}+\mathrm{NEc}\left(-1.6^{\circ} \mathrm{C}\right)$ and $\mathrm{W}+\mathrm{NWc}\left(-0.8^{\circ} \mathrm{C}\right)$ circulation.

2) In the Southward Coline stations, UTCI means are of $3.6^{\circ} \mathrm{C}$ higher than in the Northward Coline stations. In the Montane stations, such differences are slightly lower $\left(3.2^{\circ} \mathrm{C}\right)$. The greatest differences occur at advection from $\mathrm{W}+\mathrm{NWc}, \mathrm{W}+\mathrm{NWa}$ and $\mathrm{S}+\mathrm{SWc}\left(6-8^{\circ} \mathrm{C}\right.$ at the Montane stations) and $\mathrm{E}+\mathrm{SEc}, \mathrm{E}+\mathrm{SEa}$ and $\mathrm{N}+\mathrm{NEC}\left(4-6^{\circ} \mathrm{C}\right.$ at the Coline stations).

3 ) In the western part of the Northward stations, the highest occurrence of heat stress days $(4.1-9.3 \%)$ is related to S+SWa. However, in the eastern part of the northern Carparthians, HS days are most frequent $(7.5-12.1 \%)$ during $\mathrm{Cc}+\mathrm{Bc}$ circulation.

4) Thermoneutral and heat stress days are more frequent on the southward slopes in comparison to the Northward stations. The greatest differences in TN days occur during N+NE (a and c), E+SEc, and W+NW (a and c) circulation. For HS days, the greatest thermal privilege of the southward slopes is observed at $\mathrm{E}+\mathrm{SE}(\mathrm{a}, \mathrm{c}), \mathrm{S}+\mathrm{SWa}, \mathrm{Ca}+\mathrm{Ka}$ and $\mathrm{Cc}+\mathrm{Bc}$ types of circulation.

\section{Acknowledgement}

Pavol Nejedlík acknowledge the support of the VEGA grant 2/0015/18

\section{ORCID}

Błażejczyk Krzysztof (iD https://orcid.org/0000-0002-0439-6642

Nejedlik Pavol (D) https://orcid.org/0000-0003-4417-3758

Skrynyk Oleh (1) https://orcid.org/0000-0002-3714-0977

Halaś Agnieszka (iD https://orcid.org/0000-0002-0506-157X

Skrynyk Olesya (ID https://orcid.org/0000-0003-0332-5073 
MISCELLANEA GEOGRAPHICA - REGIONAL STUDIES ON DEVELOPMENT

Vol. $24 \cdot$ No. $3 \cdot 2020 \cdot$ pp. 147-160 •ISSN: 2084-6118 • DOI: 10.2478/mgrsd-2020-0022

Table 7. Differences in seasonal frequency of cold stress (dCS), thermoneutral (dTN) and heat stress days (dHS) between Southward and Northward stations

\begin{tabular}{|c|c|c|c|c|c|c|c|c|c|c|c|c|}
\hline \multirow{2}{*}{$\begin{array}{c}\text { Air } \\
\text { circulation } \\
\text { type }\end{array}$} & \multicolumn{4}{|c|}{ dCS } & \multicolumn{4}{|c|}{ dTN } & \multicolumn{4}{|c|}{ dHS } \\
\hline & MAM & JJA & SON & DJF & MAM & JJA & SON & DJF & MAM & JJA & SON & DJF \\
\hline \multicolumn{13}{|c|}{ Coline stations } \\
\hline $\mathrm{N}+\mathrm{NEa}$ & -5.9 & . & -5.6 & -17.9 & 9.8 & -5.6 & 6.5 & -0.2 & . & 3.9 & 0.5 & . \\
\hline $\mathrm{N}+\mathrm{NEc}$ & -7.9 & . & -9.8 & -25.1 & 10.2 & 5.4 & 13.1 & 0.2 & 0.6 & -0.1 & . & . \\
\hline $\mathrm{E}+$ Sea & -6.0 & . & -3.8 & -15.9 & 5.3 & -16.5 & 4.4 & 3.7 & 0.4 & 19.0 & 0.7 & . \\
\hline $\mathrm{E}+\mathrm{Sec}$ & -5.4 & . & -2.4 & -17.3 & 9.8 & -12.2 & 18.9 & 4.8 & 2.8 & 15.7 & 0.7 & . \\
\hline S+Swa & -4.5 & . & -1.8 & -13.8 & -1.1 & -11.6 & 4.5 & 4.3 & 1.4 & 22.0 & 0.4 & . \\
\hline $\mathrm{S}+\mathrm{SWc}$ & -4.6 & . & -2.5 & -11.8 & 7.0 & -11.7 & 5.9 & -1.6 & 0.6 & 15.5 & 0.3 & . \\
\hline $\mathrm{W}+\mathrm{NWa}$ & -7.1 & . & -3.7 & -14.6 & 10.9 & -11.2 & 10.6 & -1.5 & . & 3.9 & 0.0 & . \\
\hline $\mathrm{W}+\mathrm{NWc}$ & -5.4 & . & -2.8 & -13.3 & 8.4 & -4.5 & 6.5 & -1.5 & . & 3.5 & 0.1 & . \\
\hline $\mathrm{Ca}+\mathrm{Ka}$ & -3.2 & . & -1.3 & -10.5 & 1.6 & -17.8 & 4.5 & 4.3 & 0.9 & 14.1 & 0.7 & . \\
\hline $\mathrm{Cc}+\mathrm{Bc}$ & -1.7 & . & -0.4 & -8.2 & 4.1 & -10.3 & 6.6 & 0.7 & 0.7 & 11.9 & 0.9 & . \\
\hline$x$ & -2.4 & . & -1.5 & -8.1 & 4.8 & -19.1 & 9.5 & 3.0 & 0.7 & 13.1 & . & . \\
\hline Average & -4.9 & . & -3.2 & -14.2 & 6.5 & -10.5 & 8.3 & 1.5 & 1.0 & 11.1 & 0.5 & . \\
\hline \multicolumn{13}{|c|}{ Montane stations } \\
\hline $\mathrm{N}+\mathrm{NEa}$ & -5.1 & 0.4 & -1.5 & -11.2 & 12.0 & 4.3 & 9.4 & . & . & . & . & . \\
\hline $\mathrm{N}+\mathrm{NEC}$ & -2.6 & . & -2.7 & 0.5 & 3.0 & 5.4 & 1.7 & -1.2 & . & . & . & . \\
\hline $\mathrm{E}+\mathrm{Sea}$ & -2.3 & -0.3 & 2.0 & 1.8 & 8.7 & -9.0 & 0.3 & 0.0 & . & 0.3 & . & . \\
\hline $\mathrm{E}+\mathrm{Sec}$ & -3.1 & 0.9 & 0.1 & 1.7 & 0.0 & -4.5 & -1.8 & -0.5 & . & -0.5 & . & . \\
\hline S+Swa & -14.0 & . & -5.9 & -26.1 & 2.1 & -15.3 & 7.9 & 0.2 & . & 1.7 & . & . \\
\hline$S+S W c$ & -20.8 & -0.3 & -12.8 & -43.5 & 4.6 & -7.8 & 5.6 & 1.1 & . & 2.3 & . & . \\
\hline $\mathrm{W}+\mathrm{NWa}$ & -15.9 & -0.3 & -13.6 & -24.8 & 14.9 & 10.0 & 12.7 & 3.5 & . & 0.1 & . & . \\
\hline W+NWc & -19.6 & -1.3 & -22.4 & -29.7 & 6.9 & 11.5 & 7.6 & 0.4 & . & 0.1 & . & . \\
\hline $\mathrm{Ca}+\mathrm{Ka}$ & -8.5 & -0.4 & -1.8 & -10.8 & 11.1 & -1.4 & 4.4 & 1.4 & . & 0.1 & . & . \\
\hline $\mathrm{Cc}+\mathrm{Bc}$ & -11.3 & 0.3 & -6.8 & -26.0 & 3.5 & -2.8 & 2.2 & -1.0 & . & 0.1 & & . \\
\hline$x$ & -10.6 & -1.2 & -3.2 & -15.0 & 5.9 & -5.1 & -5.1 & -0.2 & . & . & . & . \\
\hline Average & -10.3 & -0.2 & -6.2 & -16.7 & 6.6 & -1.4 & 4.1 & 0.4 & . & 0.5 & . & . \\
\hline
\end{tabular}

Source: produced by author

\section{References}

Baranowski, J 1999, 'Influence of relief and land cover on wind conditions in High Tatras, Hala Gąsienicowa example' in Badania geoekologiczne w otoczeniu Kasprowego Wierchu, eds. A Kotarba \& A Kozłowska, Prace Geograficzne IGiPZ PAN, vol. 174. pp. 105-120.

Baranowski, J 2003, 'Absorbed solar radiation at Hala Gąsienicowa, Tatras' in Postępy w badaniach klimatycznych $i$ bioklimatycznych, eds K Błażejczyk, B Krawczyk \& M Kuchcik, Prace Geograficzne IGiPZ PAN, vol. 188, pp. 131-144.

Bissolli, P \& Dittmann, E 2001, 'The objective weather type classification of the German Weather Service and its possibilities of application to environmental and meteorological investigations', Met Zeit, vol. 10, no. 4, pp. 253-260.

Błażejczyk, K \& Skrynyk, O 2019, 'Principal features of Chornohora climate (Ukrainian Carpathians)', Bulletin of Geography, Physical Geography Series, vol. 17, pp. 61-76.
Błażejczyk, K 2019, 'Seasonal and multiannual variability of selected elements of climate in the Tatra and Karkonosze Mts. over the 1951-2015 period', Przegląd Geograficzny, vol. 91 , no. 1, pp. 59-80.

Błażejczyk, K, Baranowski, J, Błażejczyk, A \& Szmyd, J 2013, 'Climate and bioclimate of Hala Gąsienicowa', in Dolina Suchej Wody w Tatrach. Środowisko i jego współczesne przemiany, eds Z Rączkowska \& A Kotarba, Prace Geograficzne IGiPZ PAN, vol. 239. pp. 67-95.

Błażejczyk, K, Epstein, Y, Jendritzky, G, Staiger, H \& Tinz, B 2012, 'Comparison of UTCl to selected thermal indices', International Journal of Biometeorolgy, vol. 56, 3, pp. 515535.

Błażejczyk, K, Nejedlik, P Skrynyk, O, Halaś, A, Skrynyk, O, Błażejczyk, A \& Mikulova, K 2020, 'Influence of geographical factors on thermal stress in northern Carpathians', International Journal of Biometeorolgy (In press). 
Błażejczyk, K, Twardosz, R \& Kunert, A 2003, Variability of bio-thermal conditions in Cracow in 20th century and atmospheric circulation' in Postępy $w$ badaniach klimatycznych i bioklimatycznych, eds K Błażejczyk, B Krawczyk \& M Kuchcik, Prace Geograficzne IGiPZ PAN, vol. 188, pp. 233-246.

Bokwa, A, Murzyn, P, Krzaklewski, P, Kukułka, W \& Fijał, S 2019, 'Climate change impact on bioclimatic stimuli intensity in the Polish Western Carpathians in summer' in Zmienność klimatu Polski i Europy oraz jej cyrkulacyjne uwarunkowania, eds L Kolendowicz, E Bednorz \& AM Tomczyk, Bogucki Wydawnictwo Naukowe, Poznań, pp. 71-86.

Bower, D, McGregor, GR, Hannah, DM \& Sheridan, SC 2007, 'Development of a spatial synoptic classification scheme for western Europe', International Journal of Climatology, vol. 27, pp. 2017-2040.

Bröde, P, Fiala, D, Błażejczyk, K, Holmér, I, Jendritzky, G, Kampmann, B, Tinz, B \& Havenith, G 2012, 'Deriving the operational procedure for the Universal Thermal Climate Index (UTCI)', International Journal of Biometeorology, vol. 56 , no. 3, pp.481-494.

Cheval, S, Birsan, MV \& Dumitrescu, A 2014. 'Climate variability in the Carpathian Mountains Region over 1961-2010', Global Planet Change, vol. 118. pp. 85-96.

Dąbrowska, K \& Guzik M (eds.) 2015, Atlas of the Tatry Mountains. Abiotic nature, Tatra National Park, Zakopane.

Endler, Ch, Oehler, K \& Matzarakis, A 2010, 'Vertical gradient of climate change and climate tourism conditions in the Black Fores't, International Journal of Biometeorology, vol. 54, pp. 45-61.

Epstein, Y \& Moran, DS 2006, 'Thermal comfort and heat stress indices', Industrial Health, vol. 44, pp. 388-398.

de Freitas, CR \& Grigorieva, EA 2017, 'A comparison and appraisal of a comprehensive range of human thermal climate indices', International Journal of Biometeorology, vol. 61 pp. $487-512$

Gajić-Čapka, M \& Zaninović, K 1997, 'Changes in temperature extremes and their possible causes at the SE boundary of the Alps', Theoretical Applied Climatology, vol. 57, pp. 8994.

Hess, M 1965, 'Vertical climate zones in the Polish Western Carpathians', Zeszyty Naukowe UJ, Prace Geograficzne, vol. 11, pp. 1-267.

Huth, R, Beck, Ch, Philipp, A, Demuzere, M, Ustrnul, Z, Cahynov, M, Kysely, J \& Tveito, OE 2008, 'Classifications of atmospheric circulation patterns. Trends and directions in climate research', Annals of the New York Academy of Sciences, vol. 1146, pp. 105-152.

Instytut Geografii i Przestrzennego Zagospodarowania PAN 2020, Bioklima. Available from: <https://www.igipz.pan.pl/ bioklima.html>. [15 March 2020].

Instytut Meteorologii i Gospodarki Wodnej Państwowy Instytut Badawczy 2020, Dane pomiarowo-obserwacyjne [Measurement and observation data].Available from: <https:// dane.imgw.pl/data/dane_pomiarowo_obserwacyjne/>. [15 March 2020].

Jendritzky, G \& de Dear, R 2008, 'Adaptation and the thermal environment' in Biometeorology for Adaptation to Climate Variability and Change: Research Frontiers and Perspectives, eds KL Ebi, I Burton \& G McGregor, Springer, Heidelberg, pp. 9-32.

Kalkstein, LS \& Nicholls, MC 1996, 'A new spatial synoptic classification: application to air-mass analysis', International Journal of Climatology, vol. 16, pp. 983-1004.

Kholiavchuk, D \& Cebulska, M 2019, 'The highest monthly precipitation in the area of the Ukrainian and the Polish
Carpathian Mountains in the period from1984 to 2013', Theoretical and Applied Climatology, vol. 138, pp. 16151628.

Kolendowicz, L, Półrolniczak, M, Szyga-Pluta, K \& Bednorz, E 2018, 'Human biometeorological conditions in the southern Baltic coast based on the universal thermal climate index (UTCI)', Theoretical and Applied Climatology, vol. 134, pp. 363-379.

Konček, M (ed.) 1974, 'Climate of Tatra Mts.', Folia Geographica, vol. 4.

Lityński, J 1970, 'Classification numerique des types de circulation et des types de temps en Pologne', Cahiers de Geographie de Quebec, vol. 14. pp. 329-338.

Łupikasza, E \& Niedźwiedź, T 2016, 'Synoptic climatology of fog in selected locations of southern Poland (1966-2015)', Bulletin of Geography, Physical Geography Series, vol. 11, pp. 5-15.

Mateeva, Z \& Filipov, A 2003, 'Bioclimatic distance index in the Rila-and-Rhodopy area of Bulgaria' in Postępy w badaniach klimatycznych $i$ bioklimatycznych, eds K Błażejczyk, B Krawczyk \& M Kuchcik, Prace Geograficzne IGiPZ PAN, vol. 188 pp. 295-302.

Messeri, A, Morabito, M, Messeri, G, Brandani, G, Petralli, M, Natali, F, Grifoni, D, Crisci, A, Gensini, G \& Orlandini, S 2015, 'Weather-related flood and landslide damage: a risk index for Italian regions', PLOS ONE, vol. 10(12): e0144468.

Migała, K 2005, 'Climatic belts in European mountains and problem of global change', Acta Universitatis Wratislaviensis, vol. 2718, Studia Geograficzne, vol. 78. Wydawnictwa Uniwersytetu Wrocławskiego.

Milewski, P 2013, 'Application of the UTCI to the local bioclimate of Poland's Ziemia Kłodzka region', Geographia Polonica, vol. 86 , no. 1 , pp. 47-54.

Miszuk, B 2008, 'Characteristic of bioclimatic conditions in Karkonosze from the point of view of various forms of tourism and recreation', Prace Geograficzne UJ, vol. 120, pp. 79-91.

Morabito, M, Crisci, A, Messeri, A, Capecchi, V, Modesti, AP, Gensini, GF \& Orlandini, S 2014, 'Environmental temperature and thermal indices. What is the most effective predictor of heat-related mortality in different geographical contexts?' Scientific World Journal, vol. 2014.

Niedźwiedź, T 1983, 'The method of a synoptic-complex characterization of the climate presented upon the example of the upper Vistula river basin', Zeszyty Naukowe UJ. Prace Geograficzne, vol. 57, pp. 17-39.

Niedźwiedź, T 2003, 'Extreme precipitation events on ten northern side of the Tatra Mountains', Geographia Polonica, vol. 76, 2, pp. 13-21.

Niedźwiedź, T 2019, Calendar of air circulation types for southern Poland. Computer file, Uniwersytet Śląski, Katedra Klimatologii, Sosnowiec. Available from: <http://www. kk.wnoz.us.edu.pl/nauka/kalendarz-typow-cyrkulacji/>. [20 March 2020].

Niedźwiedź, T 2012, 'Climate' in Recent Landform Evolution. The Carpatho-Balcan-Dinaric Region, eds D Lóczy, M Stankoviansky \& A Kotarba, A, Springer, pp. 19-29.

Nowosad, M, Rodzik, B, Wereski, S \& Dobek, M 2013, 'The UTCI index in Lesko and Lublin and its circulation determinants', Geographia Polonica, vol. 86, pp. 29-36.

Ono, HSP \& Kawamura, T 1991, 'Sensible climates in monsoon Asia', International Journal of Biometeorology, vol. 35, pp. 39-47.

Osadchyi, VI, Skrynyk, OA \& Skrynyk, OY 2015, 'Estimation of a modern stage of wind resources in the Ukrainian Carpathians and their changes regarding the base climatological period', 
Dopovidi Nacionalnoi Academi Nauk Ukrainy, vol. 8, pp. 95-99.

Owczarek, M, Marosz, M \& Kitowski, M 2019, 'The influence of atmospheric circulation on the occurence of heat stress on human beings in Polish coast of Baltic Sea' in Zmienność klimatu Polski i Europy oraz jej cyrkulacyjne uwarunkowania, eds L Kolendowicz, E Bednorz \& AM Tomczyk, Bogucki Wydawnictwo Naukowe, Poznań, pp. 135-156.

Pecelj, M, Đorđević, Đ, Pecelj, MR, Pecelj-Purković, J, Filipović, D \& Šećerov, V 2017, 'Biothermal conditions on Mt. Zlatibor based on thermophysiological indices', Archives Biological Sciences, vol. 69, no. 3, pp. 455-461.

Rączkowska, Z, Łajczak, A, Margielewski, W \& Święchowicz, J 2012, 'Recent landform evolution in the Polish Carpathians' in Recent Landform Evolution: The Carpatho-Balkan-Dinaric Region, eds D Lóczy, M Stankoviansky \& A Kotarba, A, Springer Dordrecht Heidelberg London New York, pp. 47-103.

Rubel, F, Brugger, K, Haslinger, K \& Auer, I 2017, 'The climate of the European Alps: Shift of very high resolution KöppenGeiger climate zones 1800-2100', Met Zeit, vol. 26, no. 2, pp. 115-125.

Sheridan, S 2002, 'The redevelopment of a weather-type classification scheme for North America', International Journal of Climatology, vol. 22, pp. 51-68.

Sindosi, OA, Bartzokas, A, Kotroni, V \& Lagouvardos, K 2015, 'Influence of orography on precipitation amount and distribution in NW Greece; A case study', Atmospheric Research, vol. 152, pp. 105-122.

Smith, RB 2015, 'Mountain meteorology. Overview' in Encyclopedia of Atmospheric Sciences, eds GR North, J Pyle \& F Zhang, Elsevier, pp. 57-61.

Spinoni, J, Szalai, S, Szentimrey, T, Lakatos, M, Bihari, Z, Nagy, A, Németh, Á, Kovács, T, Mihic, D, Dacic, M, Petrovic, P, Kržič, A, Hiebl, J, Auer, I, Milkovic, J, Štepánek, P, Zahradnícek, P, Kilar, P, Limanowka, D, Pyrc, R, Cheval, S, Birsan, MV, Dumitrescu, A, Deak, G, Matei, M, Antolovic, I, Nejedlík, P, Štastný, P, Kajaba, P, Bochnícek, O, Galo, D, Mikulová, K, Nabyvanets, Y, Skrynyk, O, Krakovska, S, Gnatiuk, N, Tolasz, R, Antofie, T \& Vogt, J 2014, 'Climate of the Carpathian Region in the period 1961-2010: Climatologies and trends of 10 variables', International Journal of Climatology, vol, 35 , no. 7, pp. 1322-1341.

Trepińska, J 2002, Mountain climates, Wydawnictwo IGiGP UJ, Kraków.

Twardosz, R 1999, 'Precipitation variability and tendency in Kraków for the period 1850-1997 related to circulation patterns', Acta Geophica Polonica, vol. 47, pp. 111-133.

Twardosz, R 2007, 'Diurnal variation of precipitation frequency in the warm half of the year according to circulation types in Kraków, South Poland', Theoretical and Applied Climatology, vol. 89, pp. 229-238.

Urban, A \& Kyselý, J 2014, 'Comparison of UTCI with other thermal indices in the assessment of heat and cold effects on Cardiovascular Mortality in the Czech Republic', International Journal of Environmental Research and Public Health, vol. 11, pp. 952-967.

Vallorani, R, Bartolini, G, Betti, G, Crisci, A, Gozzini, B, Grifoni, D, lannuccilli, M, Messeri, A, Messeri, G, Morabito, M \& Maracchi, G 2017, 'Circulation type classifications for temperature and precipitation stratification in Italy', International Journal of Climatology, vol. 38, no. 2, pp. 915931.

Zaninović, K, Matzarakis, A \& Cegnar, T 2006, 'Thermal comfort trends and variability in the Croatian and Slovenian mountains', Met Zeit, vol. 15, no. 2, pp. 243-251.
Żmudzka, E \& Kulesza, K 2019, 'Total solar radiation in Zakopane and at mount Kasprowy Wierch in 1986-2015', Geographia Polonica, vol. 92, no. 2, pp. 211-231.

Żmudzka, E 2009, 'Changes of thermal conditions in the Polish Tatra Mountains', Landform Analysis, vol. 10, pp. 140-146.

Żmudzka, E 2011, 'Contemporary climate changes in the high mountain part of the Tatras', Miscellanea Geographica, vol. 15, pp. 93-102. 